Copyright (C) 1983 by Academic Press, Inc. All rights of reproduction in any form reserved $0014-4827 / 83 / 020475-05 \$ 02.00 / 0$

\section{Macrophages express cell surface laminin}

MAX S. WICHA and THOMAS K. HUARD, Division of Hematology and Oncology, Simpson Research Institute, University of Michigan, Ann Arbor, MI 48109, USA

SUMMARY. Laminin, a non-collagenous extracellular connective tissue glycoprotein, was detected on the surface of mouse peritoneal macrophages. As determined by indirect immunofluorescence, as many as $60 \%$ of peritoneal macrophages elicited with thioglycollate expressed cell surface laminin. Only $14 \%$ of resident cells displayed detectable laminin. The expression of laminin increased with time post-injection. Concomitant with laminin expression, macrophages also displayed a receptor for the $\mathrm{IB}_{4}$ isolectin from Griffonia simplicifolia. This lectin, which binds methyl- $\alpha$-D-galactopyranoside, may also react with the carbohydrate moeity of laminin. A small population of macrophages displayed both laminin and surface fibronectin. Unlike the difference in laminin expression between resident and thioglycollatestimulated cells, there was no difference in cell surface fibronectin between these cell populations. Since laminin has been found to mediate cell attachment in other systems, expression of this molecule on the surface of stimulated macrophages may be important in cell-cell and cell-matrix adhesive properties of these cells.

In response to tissue injury and inflammation, blood mononuclear cells must attach to and traverse the vascular endothelial cell layer and its underlying basement membrane. Although it has been assumed that macrophage cell surface molecules play a role in these processes, the mechanisms involved are poorly understood. It has recently been reported that stimulated mouse macrophages, unlike resident macrophages, express a glycoprotein receptor which is reactive with the lectin $\mathrm{IB}_{4}$ isolated from Griffonia simplicifolia (also known as lectin I (GSI) [1]. This lectin, which specifically recognizes terminal $\alpha$-linked galactopyranosyl residues, has also been found to bind to basement membrane components [2]. One of these components, laminin, is a glycoprotein of approx. 800000 molecular weight [3] which is found in the lamina lucida of basement membranes $[4,5]$. This glycoprotein has been reported to mediate the attachment of epithelial cells to the collagenous component of basement membranes (type IV collagen) [6]. We now report that stimulated mouse peritoneal macrophages express cell surface laminin as determined by indirect immunofluorescence. This molecule may play an important role in macrophage matrix and macrophage-cell interactions.

\section{Materials and Methods}

Cell isolations. Murine peritoneal exudate cells (pEC) were obtained from normal C57BL/6J 8 week oid female mice (Jackson Labs, Bar Harbor, ME) and used as a source of macrophages. The PEC were elicited by injection of $1 \mathrm{ml}$ of sterile thioglycollate broth (Difco, Detroit, MI) per mouse 4 days prior to collecting the PEC (cell yield $\sim 2 \times 10^{7} /$ mouse). The PEC were collected by lavage of the peritoneal cavity with $10 \mathrm{ml}$ of Hank's Balanced Salt Solution (HBSS) per mouse [7]. The cells were washed wice with cold $\left(4^{\circ} \mathrm{C}\right)$ HBSS and adjusted to $1 \times 10^{6} / \mathrm{ml}$ in HBSS. The cells were $\geqslant 95 \%$ viable (trypan bine exclusion), $\geqslant 90 \%$ non-specific esterase-positive [8], and the majority of cells had macrophage-like morphology by differential staining (Wright's stain) of cytospin preparations with $\leqslant 10 \%$ contamination by lymphocytes and granulocytes. Resident peritoneal cells were collected from 2 to 4 normal non-injected mice for each experiment (cell yield $\sim 2 \times 10^{6} /$ mouse). The resident cells were $\geqslant 95 \%$ viable, $\geqslant 31 \%$ non-specific esterase positive, $\leqslant 62 \%$ adherent, and $\leqslant 67 \%$ had macrophage-like morphology.

Antisera preparation. Laminin was isolated from the basement membrane producing EHS sarcoma (a gift from Dr Lance Liotta, NiH) [3]. The purity of the preparation was confirmed by SDS polyacrylamide gel electrophoresis as previously described [3]. Anti-laminin antibodies were raised in rabbits immunized with laminin and purified by affiniry chromatography on a column of laminin coupled to Sepharose $4 B[4]$. The antisera reacted only with basement membranes in all tissues studied including frozen sections of kidney, lung, and mammary gland. Immunodiffusion revealed a sisigle precipitin line with purified EHS laminin, but no reaction with type IV collagen or fibronectin. Well characterized antilaminin antibodies produced in sheep and purifed by afrinity chromatography [3], obtained from Dr Lance Liotta, NIH, gave identical results in indirect immunofluorescence assays.

Fluorescence binding assays. Freshly harvested non-fixed mouse macrophages were processed for immunofluorescence as previously described [9]. Briefly, $1 \times 10^{6}$ cells were incuhated for $1 \mathrm{~h}$ with $50 \mathrm{\mu l}$ of a 50:1 dilution of anti-laminin antisera in a humidified chamber at ambient temperature. After washirig 

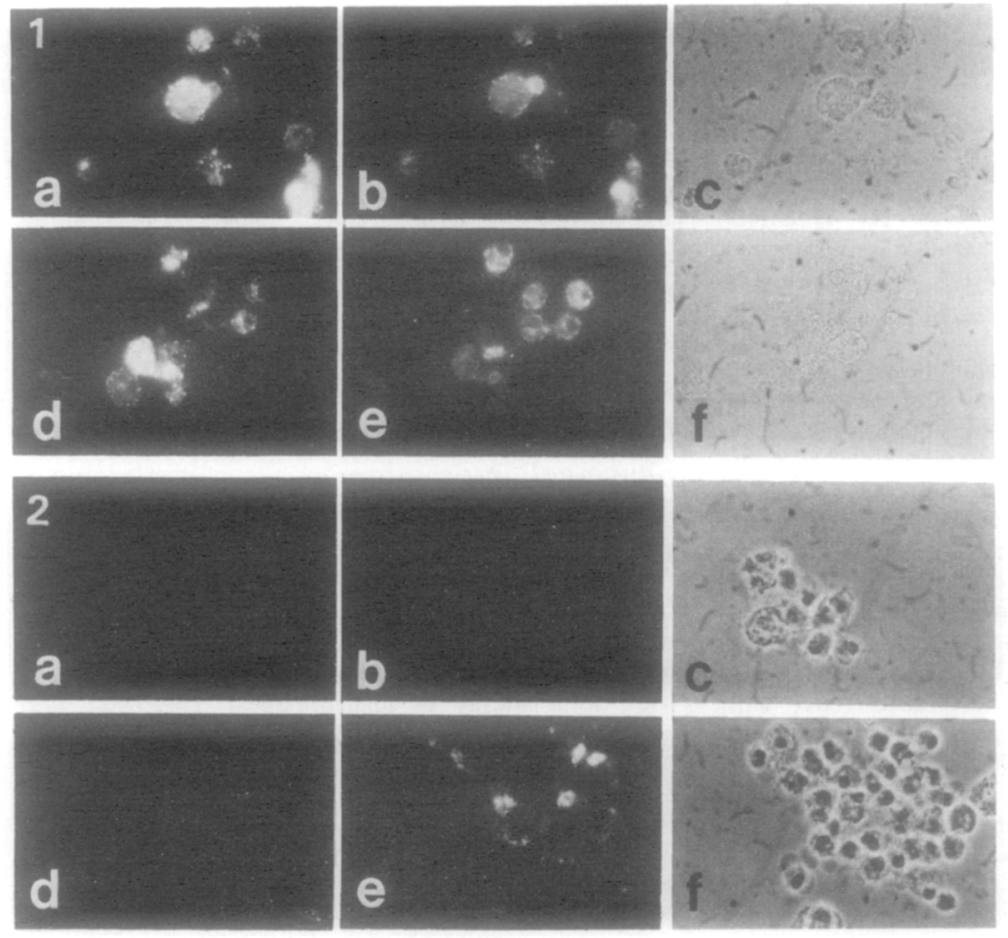

Fig. 1, 2. Expression of laminin, $\mathrm{IB}_{4}$ receptor and fibronectin on (fig. . 1) thioglycollate-elicited peritoneal màcrophages (4 days); (fig. 2) resident peritoneal cells. Fluorescence exposure 1 min. (a) RITC-laminin; (b) FITC-IB 4 lectin; (c) phase contrast of $(a),(b)$; d(d) RITC-laminin; (e) FITC-fibronectin; $(f)$ phase contrast of $(d),(e) . \times 630$. five times with cold $\left(4^{\circ} \mathrm{C}\right)$ phosphate-buffered saline (PBS), pH 7.4, the cells were incubated with $50 \mu \mathrm{l}$ of a $1: 20$ dilution of tetramethyl chloramine (rhodamine) isothiocyanate (RITC)-conjugated goat antirabbit IgG (Cappel Labs, Philadelphia, PA) for 30 min. Following washing with cold PBS (five times), the cells were incubated with either fluorescein isothiocyanate (FITC)-conjugated rabbit anti-rat fibronectin (Cappel) or FITC-conjugated isolectin $\left(\mathrm{IB}_{4}\right)$ from Griffonia simplicifolia (Sigma) for an additional 30 min. After washing five times with cold PBS, cells were mounted in $10 \%$ glycerol: $90 \%$ PBS, examined for fluorescence with a Leitz epi-illuminated microscope equipped with filters and photographed with Kodak Tri-X film. The percent of cells stained were determined by counting at least 200 cells per field in 2-3 fields per group. All fluorescence count determinations were performed by two observers independently and agreed within $10 \%$.

\section{Results}

We compared the expression of cell surface laminin, fibronectin, and an $\mathrm{IB}_{4}$ lectinbinding receptor on resident and thioglycollate-elicited murine peritoneal cells by immunofluorescence. As shown in figs 1 and 2, thioglycollate-elicited macrophages bound both anti-laminin antibody and $\mathrm{IB}_{4}$ lectin. At least $50 \%$ of the macrophages expressed membrane-bound laminin, and more than $20 \%$ were $\mathrm{IB}_{4}$-positive (table 1 , fig. 1). Only $14 \%$ of the resident cell population were positive for laminin and $2 \%$ for $\mathrm{IB}_{4}$ receptor (table 1, fig. 2). Concurrently, the percentage of cells displaying fibronectin was only moderately elevated in stimulated vs resident cell populations (table 1, fig. 1). Incubation of the macrophages with anti-laminin antisera and $10 \mu \mathrm{g}$ of purified EHS laminin inhibited the detection of cell-bound laminin while not effecting the binding of $\mathrm{IB}_{4}$. Pretreatment of the macrophages with normal human serum did not affect subsequent binding of antilaminin or anti-fibronectin antibodies. This observation plus the failure of non-immune rabbit serum to bind to the cell surface indicates that the binding of anti-laminin 
Table 1. Detectio of cell surface lamine ${ }^{e}$

\begin{tabular}{|c|c|c|c|c|c|}
\hline Cell population $^{a}$ & $\underset{(\%)}{\operatorname{Laminin}^{b}}$ & $\begin{array}{l}\mathrm{B}_{4} \\
(\%)\end{array}$ & $\begin{array}{l}\text { Fibro- } \\
\text { nectin } \\
(\%)\end{array}$ & $\begin{array}{l}\text { Double } \\
(\%)\end{array}$ & $\begin{array}{l}\text { None } \\
(\%)\end{array}$ \\
\hline Resident & 14 & 2 & - & 2 & 84 \\
\hline Resident & 8 & - & 25 & 6 & 67 \\
\hline Thioglycollate-elicited & $53^{f}$ & $22^{f}$ & - & 14 & 25 \\
\hline Thioglycollate-elicited & $50^{f}$ & - & 35 & 32 & 15 \\
\hline Thioglycollate-elicited + laminin $^{d}$ & 14 & $24^{f}$ & - & - & - \\
\hline
\end{tabular}

a Resident or thioglycollate-elicited ( $1 \mathrm{ml}$, IP) (4 days) peritoneal cells from normal C57BL/6 mice.

$b \%$ cells staining for laminin by indirect immunofluorescence.

${ }^{c}$ cells staining for fibronectin or $\mathrm{IB}_{4}$ lectin by direct immunofluorescence.

a Inhibition with exogenous laminin $(10 \mu \mathrm{g})$.

$e$ One representative experiment of eight.

${ }^{f}$ Statistically significant from resident cells $(p>0.05$ by $t$-test).

and anti-fibronectin antibodies are not mediated by non-specific binding to macrophage $F c$ receptors. Similarly, incubation of the $\mathrm{IB}_{4}$ lectin with the macrophages in the presence of the haptenic sugar methyl $\alpha$-D-galactopyranoside, blocked $\mathrm{IB}_{4}$ binding, but did not significantly reduce antilaminin binding (not shown). Changing the order of staining of the cells for double immunofluorescence assays or adding single fluorescent agents only did not alter the percentage of positive cells for either laminin or $\mathrm{IB}_{4}$.

Although the elicited PEC showed considerably more binding of both anti-laminin antibodies and $\mathrm{IB}_{4}$ lectin than resident cells, distinct subpopulations of cells were detectable. Some bound only anti-laminin or $I_{4}$, whereas a smaller subpopulation was doubly positive (fig. 1, table 1). There was no relationship between the binding of these agents to the expression of fibronectin on either cell population (table 2). Almost all the elicited PEC that expressed fibronectin also exhibited membrane-bound laminin.

The kinetics of appearance of cell surface molecules after in vivo stimulation with thioglycollate is shown in table 2. Al- though the accumulation of PEC was maximum by 4 days after thioglycollate stimulation, the percent of laminin-positive cells continued to increase so that $60 \%$ of the stimulated macrophages were laminin-pos:tive by 7 days after stimulation.

\section{Discussion}

We have demonstrated by immunofluorescence that inflammatory macrophages express a cell surface molecule which im-

Table 2. Kinetics of cell surface laminin expressione

\begin{tabular}{|c|c|c|c|}
\hline Cell population ${ }^{a}$ & Day $^{b}$ & $\begin{array}{l}\text { Lami- } \\
\text { ninte } \\
(\%)\end{array}$ & $\begin{array}{l}\text { Cell } \\
\text { yield }\end{array}$ \\
\hline Resident & 0 & 14 & $2.3 \times 10^{6}$ \\
\hline Thioglycollate-elicited & 1 & 21 & $11.3 \times 10^{6}$ \\
\hline Thioglycollate-elicited & 2 & - & - \\
\hline Thioglycollate-elicited & 3 & 50 & $22.5 \times 10^{6}$ \\
\hline Thioglycollate-elicited & 4 & 53 & $24.3 \times 10^{6}$ \\
\hline Thioglycollate-elicited & 5 & 53 & $16.2 \times 10^{6}$ \\
\hline Thioglycollate-elicited & 6 & 55 & $11.7 \pm 10^{\circ}$ \\
\hline Thioglycollate-elicited & 7 & 60 & $7.7 \times 10^{6}$ \\
\hline
\end{tabular}

$a^{a}$ Resident or thioglycollate-eliciced (1 $\mathrm{ml}$; IP) peritoneal cells from normal C57BL/6J mice.

${ }^{\circ}$ Days cells were isolated post-thioglycollate stimulation.

c\% cells staining for laminin by indirect immunofluorescence.

${ }^{a}$ Mean number cells isolated/mouse.

- Mean of two comparable experiments. 
munologically resembles the basement membrane glycoprotein laminin. In contrast to the resident peritoneal population, these cells also display a receptor for the $\mathrm{IB}_{4}$ lectin from $G$. simplicifolia, as has recently been reported by Maddox et al. [1]. Although the $\mathrm{IB}_{4}$ isolectin binds to purified EHS laminin [10], we observed subpopulations of the macrophages which bound either anti-laminin antibody or $\mathrm{IB}_{4}$ lectin and others which bound both (table 1). In addition, exogenous laminin or the lectinspecific ligand methyl- $\alpha$-D-galactopyranoside showed little cross-reactivity in inhibition of immunofluorescence. This may indicate that surface glycoproteins other than laminin expressed on macrophages contain terminal $\alpha$-linked galactopyranosyl groups and/or that there are differences in binding affinities of anti-laminin antibody and $\mathrm{IB}_{4}$ leading to distinct thresholds of sensitivity.

Mononuclear phagocytes (e.g., alveolar macrophages) have been shown to synthesize fibronectin $[11,12]$. In contrast to the marked increase in cell surface laminin and $\mathrm{IB}_{4}$ lectin-binding receptor on stimulated $\mathrm{PEC}$, there was little difference in the expression of cell surface fibronectin on either resident or stimulated cell population. Our results suggest that there are differences in the expression of the attachment glycoproteins, laminin and fibronectin, on these populations of cells. These differences may be important in determining macrophageadhesive properties, since laminin and fibronectin recognize different substrates for attachment [13].

It is not clear whether the laminin expressed on the macrophage cell surface during stimulation represents de novo synthesis by the macrophage or adsorption of exogenous laminin to the cell surface. It is also unclear why the kinctics of laminin expression lag behind the accumulation of cells in the peritoneal fluid following stimulation. This suggests that the expression of cell surface laminin may reflect a state of macrophage differentiation. Experiments are currently under way to investigate these possibilities. Giavazzi et al. have recently found that exogenous laminin inhibits the attachment of thioglycollate-elicited mouse macrophages to basement membrane (type IV) collagen [14]. Our findings provide an explanation for this observation, since exogenously added laminin would compete with laminin on the macrophage cell surface for binding to laminin receptor sites on type IV collagen.

The role of laminin in macrophage function is unclear. Laminin which is present in the lamina lucida of basement membranes, next to the epithelial cell surface, has been found to mediate the attachment of epithelial cells to basement membrane collagen in vitro [6]. This property is not limited to cells of epithelial origin, since we have recently found that a highly metastatic subline of a murine fibrosarcoma expresses more surface laminin and binds the $\mathrm{IB}_{4}$ lectin considerably more than a low metastatic subline from the same tumor [10]. In addition, we have shown that exogenous laminin promotes the attachment of the low malignant variant to type IV collagen. Terranova et al. have also shown that metastatic tumor cells have the ability to attach to basement membrane collagen via laminin [15]. It may be that mononuclear phagocytic cells which, like metastasizing tumor cells, must attach to and traverse basement membrane, also have the ability to utilize cell surface laminin in this process. Laminin may also play a role in the interaction of macrophages with other cells including tumor cells which have been shown to be capable of laminin binding [15]. Further studies are necessary to 
elucidate these roles of laminin in macrophage function.

Thanks are due to Dr Lance Liotta (NIH) for supplying EHS sarcoma basement membrane material and an aliquot of sheep anti-EHS laminin antibody, and to Dr Irwin Goldstein for help in preparation of anti-laminin antibodies. We also express our appreciation to $\mathrm{Mr}$ George Lowrie for his technical assistance.

This work was supported by grant BC357 from the ACS, USPHS grant CA25641 from the NCI, DHHS, and HD 16721-01 from the NIH.

\section{References}

1. Maddox, D E, Shibata, S, Goldstein, I J, Proc natl acad sci US 79 (1982) 166.

2. Peters, B P \& Goldstein, I J, Exp cell res 120 (1979) 321.

3. Timpl, R, Rhode, H, Robey, P G, Rennard, S I, Foidart, J M \& Martin, G R, J biol chem 254 (1979) 9933.

4. Rhode, H, Wick, $G$ \& Timpl, R, Eur $\mathrm{j}$ biochem 02 (1979) 195.

5. Foidart, J M, Bere, E W, Yaar, M, Rennard, S I, Gullino, M, Martin, G R \& Katz, S I, Lab invest $42(1980) 336$.

6. Tcrtanova, V P, Bohrbach, D II \& Martin, G R, Cell 22 (1980) 719 .

7. Conrad, R E, Manual of macrophage methodology (ed H B Herscowitz, H T Holden, J A Bellant \& A Ghaffar) p. 5. Marcel Dekker, New York (1981).

8. Tucker, S B, Pierre, R V \& Jordan, R E, J immunol methods 14 (1977) 267.

9. Wicha, M S, Liotta, L A, Vonderhaar, B K \& Kidwell, W R, Dev biol 253 (1980) 266.

10. Varani, J, Lovett, E J, McCoy, P, Shibata, S, Maddox, D, Goldstein, I \& Wicha, M, Am j pathol. In press (1982).

11. Villiger, B, Kelley, D G, Engleman, W, Kuhn, C \& McDonald, J A, J cell biol 90 (1981) 711.

12. Rennard, S E, Hunninghake, G W, Bitterman, P B \& Crystal, R G, Proc natl acad sci US 78 (1981) 7147 .

13. Hay, E, J cell biol 91 (1981) 2055.

14. Giavazzi, R, Liotta, L \& Hart, I, Exp cell res $140(1982) 315$.

15. Terranova, V P, Foltz, C, Murray, J C \& Martin, G R, Am assoc cancer res 22 (1981) $55 \mathrm{~A}$.

Received June 18, 1982

Revised version received October 21,1982

Accepted October 26, 1982 